\title{
AL-ITQĀN
}

JOURNAL OF ISLAMIC SCIENCES AND COMPARATIVE STUDIES

\section{Volume: 3}

Issue No. 2

December 2019

EDITOR IN-CHIEF

Dr. Wan Mohd Azam Mohd Amin

\section{MANAGING EDITOR}

Dr. Masitoh Ahmad

EDITORIAL BOARD

Dr. Syed Arabi Aidid, IIUM.

Dr. Hassan Basri Mat Dahan, Universiti Sains Islam Malaysia,

Nilai, Negeri Sembilan

Dr. Kamaruzaman Yusuff, Universiti Malaysia Sarawak,

Kota Semarahan, Kucing.

Dr. Kamar Oniah, IIUM.

Dr. Mumtaz Ali, IIUM.

Dr. Noor Amali Mohd Daud, IIUM.

Dr. Adibah Abdul Rahim, IIUM.

Dr. Haslina Ibrahim, IIUM.

Dr. Siti Akmar, Universiti Institut Teknologi MARA, Shah Alam

Dr. Thameem Ushama, IIUM. 


\section{INTERNATIONAL ADVISORY BOARD}

Dr. Muhammad Afifi al-Akiti, Oxford University, UK

Dr. Abdullah M. al-Syarqawi, Cairo University, Egypt.

Dr. Abdul Kabir Hussain Solihu, Kwara State University, Nigeria.

Dr. Anis Ahmad, Riphah International University, Islamabad.

Dr. ASM Shihabuddin, Uttara University, Dhakka, Bangladesh.

Dr. Fatimah Abdullah, Sabahattin Zaim University,Turkey.

Dr. Ibrahim M. Zein, Qatar Foundation, Qatar.

Dr. Khalid Yahya, Temple University, USA.

(C) 2017 IIUM Press, International Islamic University Malaysia. All rights reserved. eISSN:26008432

\section{Correspondence}

Managing Editor, Al-Itqān

Research Management Centre, RMC

International Islamic University Malaysia

P.O Box 10, 50728 Kuala Lumpur, Malaysia

Tel: +60361965558

Website: http://journals.iium.edu.my/al-itqan/index.php/alitqan/index

Email: al-itqan@iium.edu.my

Published by:

IIUM Press, International Islamic University Malaysia

P.O. Box 10, 50728 Kuala Lumpur, Malaysia

Phone (+603) 6196-5014, Fax: (+603) 6196-6298

Website: http://iiumpress.iium.edu.my/bookshop 


\section{Table of Contents}

Tawakkul: Exemplary Deeds of the Mother and the Sister of

Prophet Mūsā.

Che' Amnah Bahari

Islam and Buddhism: Similarities of Moral Practices.

Nur Suriya Mohd Nor

$23-40$

Jesus (pbuh) as "son of God": A Biblical Study Based on the

Jewish Scriptures and the Gospel of Matthew.

$41-64$

Ungaran@Rashid

A Contrastive Analysis of Yusuf Islam and Zakir Naik's Styles of Religious Propagation or Preaching.

Maziah Mustapha

$65-86$

Mohd Abbas Abdul Razak

Muslim-Christian Relationship in the Light Of Qur'an and

Sunnah: An Assessment of the Causes of Religious Crises in Multi Religious Nigeria.

$87-113$

Ishiaku, Safiyanu \& Modibbo, Yakubu, Aliyu, Muhammad Tanko

Existing Framework of Inter-Religious Dialogue in Malaysia.

Suraya Mohamed Yasin

$115-145$

Women Curative Protection on the Violence Victims: The Relevance of Maqāsid al Sharī'ah al-Islämiyah on the Justice Access.

$147-162$

Nurul Adhha

Sufi Values and Contemporary Pseudo Sufism in Nigeria.

Shehu Abdur-Rahman Aboki

$163-180$

Legislative Distinction of Muslims from the Heretic Groups Based on Qur'an and Prophetic Hadīth with Special Reference on the Doctrinal Issues.

Zunaidah Mohd Marzuki

Extracting the Source of Theological Logic Evidence from "al- 'Aqīdah al-Burhāniyah" by Abū 'Amr 'Uthmān al-Salālijīi, (Died 574 H) 


\section{Author Guidelines}

1. Manuscript article can be either in English, Malay or Arabic using software Microsoft office (Word, and Excel), Font 12 Times New Roman. Only tables, figures and appendix can be written using Font 10, Times New Roman.

2. If there is a usage of Quranic verses or Hadith fom Prophet P.B.U.H., it only needs to be done by translation only.

3. The manuscript should be in 1.5 single spacing and justified, with the margin of $2.5 \mathrm{~cm}$.

4. Article needs to have a title and author's name and second author's name along with the full address (institution's or university's address, e-mail, handphone's number, office's number, fax together with the second author's details).

5. Every article must include an 'abstract in Malay and English. The length of the abstract is no more than 150 words including 5 keywords.

6. The length of each article must not exceed 6000 words.

7. The Arabic words in manuscript should be in a transliterated form.

8. Reference for each article must be written according to Chicago Manual.

9. Notification Letter :

10. Letter of Acceptance - editorial board will send an e-mail to the author to notify that the manuscript is received.

11. Letter of Acceptance/Rejection for Publication - editorial board will send a letter by an e-mail to the author to notify if the manuscript judged by the panels is approved or declined to be published.

12. Letter of Publication - editorial board will send a letter by e-mail to the author if the article has been judged, repaired, and corrected to be published in the college's journal.

13. Certificate of Appreciation- editorial board will send a certificate of appreciation by mail to the authors who have sent their articles. 


\title{
Tawakkul: Exemplary Deeds of the Mother and The Sister of Prophet Mūsā
}

\author{
Che Amnah Bahari*
}

\begin{abstract}
Tawakkul or reliance on God has a strong relationship with imān (faith) in Him. It also refers to taqwā or God consciousness. Al-Qur'ān for that matter has stipulated success depends on one's complete reliance on Him, steadfast in obeying and fulfilling all the commandments postulated by Him. This would mean that tawakkul requires the essential steps needed to achieve the goals and so the act of striving for the goals is an act of submission while believing and reliant on God is faith in Him. This paper attempts to study Qur'ānic approach to tawakkul in connection with the uncertainties faced by the mother and sister of Prophet Mūsā to protect baby Mūsā from evil deeds of Fir'aūn. It also discusses the good-natured actions applied by them to overcome their fears. This paper ends by explaining the relevancy of practicing the correct method of tawakkul and the impact on wellbeing of mind.
\end{abstract}

Keywords: Tawakkul, taqwā, uncertainties, good-natured action

\section{Introduction}

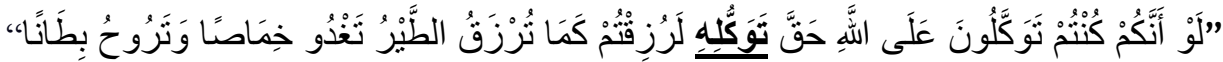
If you were to rely on Allah with the required reliance, then He would provide for you just as a bird is provided for, it goes out in the morning empty, and returns full."

Tawakkul or reliance as indicated in the above citation reflects that reliance on Allah is to work and involve in searching for permissible source of income. At the same time while so doing, one is relying on Divine power, sources and wealth for his/her sustenance. The reliance as highlighted in the hadith is an analogy to explain the act of birds that does not sitting idle for spoon feeding rather searching for it wherever they could and return to their nests with full bellies. It is not a one-way relationship

\footnotetext{
*Assoc. Prof. Dr., Department of Ușūl al-Dīn and Comparative Religion, Kulliyyah of Islamic Revealed Knowledge and Human Siences, International Islamic University Malaysia. Email: amnah@iium.edu.my

${ }^{1}$ Muḥammad ibn 'Īsā al-Tirmidhī, Jāmi' al-Tirmidhī, (Jaddah: Dār al-Salām, 2007) Vol. 4, Book 10, Hadīth 2344, cited as Jämi ‘ al-Tirmidhì.
} 
rather it shows a two-way dimension whereby; one fulfills the responsibly related to his/her affair and rely the result from Allah, be it good or bad.

The term tawakkul, literally originates from the root word, wakala which means to entrust, assign and appoint someone else or wakil for your affairs. ${ }^{1}$ According to Ibn Manzūur (d.1113 AH / $1701 \mathrm{CE}$ ), tawakkul is of two aspects. First - tawallaytu lahu means to turn to someone and the second, $i$ 'tamadtuhu refers to rely on someone. ${ }^{2}$ In al-Qur'ān the term $i$ 'tamadtuhu is not found but tawalla is sporadically applied in transitive sense. For examples - tuwallu brings the meaning "to turn in a physical sense" (Sürat al-Baqarah, 2:177) or tawallau means "to turn away from someone" (Sürat al-Baqarah, 2:246) and yatawalla refers to "As those who turn (for friendship) to Allah, His Messenger and the fellowship of the believers - it is the fellowship of Allah that must certainly triumph"'(Sürat al-Mà'idah, 5:56). In verse three (3) of Sürat al-Talāq, the term yatawakkal reflects a wider dimension - "And whoever places his trust and reliance in Allah then He will suffice him".

These evidences intrinsically say that to practice tawakkul requires one's knowledge on the wakill's ability such as well inform, trustworthy, powerful to undertake the task and concern of the wellbeing of the tukalah (clients/one who puts the reliance). In other words, a true believer needs to have self-confidence in God as his Wakil, such as selfknowledge on the greatness or supremacy of his Wakil, knowledge of his duties to his Wakil and knowledge of true and guided utilization of all resources and materials conferred to him by his Wakil for the purpose of fulfilling his submission to his Lord. At the same time the believer is aware that life of full of tribulations and having built the self-confidence in his Wakil, shall incite in him the courage to confront any looming evils in his path impinging his acts of submission. He shall not feel weak or humiliated rather relying on the boundless power of his Wakil and should feel the victory of overcoming the tribulations.

Further readings on the concept of tawakkul ${ }^{3}$ reveal that relying on God is rendered extensively in al-Qur'ān using various forms of

\footnotetext{
${ }^{1}$ Ibn Manzūr, Lisān al- 'Arab, (Bayrūt: Dār al-Ṣādr, 1994), vol. 11, pp. 734-736, cited as Lisān al- 'Arab.

${ }^{2}$ Ibid, p. 736.

${ }^{3}$ See al-Muhāsibi, al-Ḥārith ibn Asad, Al-Makāsib wa al-Rizq al-Halāl wa Haquiqat alTawakkul, (Al-Qāhirah: Maktabah al-Qur'ān, 1984); Binyamin Abrahamov, Ibn al'Arabi and the Sufis (Oxford: Anqa Publishing, 2014); Burrel, David, Al-Ghazali Faith in Divine Unity and Trust in Divine Providence - Kitāb al-Tawhìd wa alTawakkul, (Louisville, KY: Fons Vitae, 2006).
} 
tawakkala and mutawakkil. It is noted that tawakkul strongly correlates with the state of $\overline{i m a \bar{n}}$ (faith), the religious practice of salät (prayers), the social practice of infāq (spending out of God's bounties) and the experiential state of wajal (awe).

Al-Mu'minūn (true believers) are wajilat qulūbuhum (those whose hearts tremble with awe) when God is mentioned, zädathum ìmānan (whose faith increases) when His revelations are recited to them, wa alä rabbihim yatawakkalūna (who put their trust in their Lord), yuqümūna al-șaläta (who keep up the prayer) and yunfiqūna (give to others) out of what We provide for them (Sürat al-Anfäl, 8:2-3).

Ibn Kathir (d. 120AH / 738CE) in the context of tawakkul as cited in the above verses, states that tawakkul is the result of believers' intense submission to their Lord through salät and infāq. ${ }^{1}$ In other words the outcome of the earnest submission to God through salat and infāq, the believers rejoice and desire to be near to God, hope in Him alone, unswerving dedication to Him alone, seek protection with Him alone, invoke Him alone for their various needs and beseech to Him alone. They know that whatever He wills, occurs and whatever He does not, will never occurs, that $\mathrm{He}$ alone is the One Who has the decision in His kingdom; none can avert the decision of Him, and He is swift in reckoning. ${ }^{2}$

As for the verse that speaks "tawakkul brings about wajal" Sayyid Qutb (d. 1386 AH / 1966 CE) clarifies that wajal is a feeling of awe that fills believers' heart when God's name is mentioned in connection with any duty. ${ }^{3}$ While performing the duty, the believers feel God's greatness, majesty, greatness and recall their defective attitude. This "burning sensation and trembling" in turn motivates them to intensify their action of submission ${ }^{4}$ in the form of salät and infāq that eventually provide solace to them. This will reinforce the nature of true believers who take precaution of doing things and "... put their trust in their Lord". The outcome of those actions will be accepted by them unreservedly and fervently hope that they be rewarded for so doing in their obedience to God. ${ }^{5}$ Due to this good-nature of acceptance and obedience, God affirmed

\footnotetext{
${ }^{1}$ Ibn Kathīr, Abū al-Fidā' Ismā̄êl, Mukhtașar Tafsīr Ibn Kathīr, (Bayrūt: Dār al-Qalam, 1991), vol. 3, pp. 619-621, cited as Tafsīr Ibn Kathìr.

${ }^{2}$ Tafsìr Ibn Kathīr, vol. 3, pp. 619-621.

${ }^{3}$ Sayyid Qutb, In the Shade of the Qur'ann, (Leicester: The Islamic Foundation 1999), vol. 7 p. 64, cited as In the Shade of the Qur'ān.

${ }^{4}$ Ibid, p. 65.

${ }^{5}$ Ibid. p. 66.
} 
and promised that ".... They shall be given high ranks with their Lord, and forgiveness of sins and generous provisions" "Hence, just as the true believers believe in truth and do right in obedience to God's command and in turn God also made good His Promise by giving them victory. Mawdūdī (d.1399 AH /1979 CE) further enlightens readers that the verse on promise means the shortcomings of the believers shall be forgiven, gives great solace to them. ${ }^{2}$ However, believers may be great and good but are liable to commit offenses. And it is not at all possible that all human being will always do good deeds correct at all time and free from defect, deficiency and fault. God, however, shows one of His greatest blessings to those who patiently perform obligatory duties, and forgives their shortcomings by His grace, and rewards His servants with a far greater recompense than the one they deserve. ${ }^{3}$

In brief, tawakkul leads believers to feel the tremor and awe before their Wakil, Who in turn inspires, revitalizes and regenerates endurance and resilience in themselves due to their earnest submission to Him. The question arises in mind, how does the concept of tawakkul befits the deeds of the mother and sister of Prophet Mūsā? How relevant are their deeds in today's context? The following discussion will briefly discuss on Qur'ānic exposition on the mother and sister of Prophet Mūsā.

\section{Qur'ānic exposition on the mother and sister of Prophet Mūsā}

The narration of Prophet Mūsā is frequently repeated in many places in al-Qur'ān, right from his birth up to the end of his life. ${ }^{4}$ The reason behind this recurrence is to explain the valuable experiences of Prophet Mūsā that could contribute to people on various levels be it individual, community and the leadership level. ${ }^{5}$ The resemblance of experiences between Prophet Mūsā and Prophet Muhammad is another important reason that necessitates such focus on the repeated narrations of Prophet Mūsā. ${ }^{6}$ Due to these reasons also, this paper will focus on the role of Prophet Mūsā's mother and sister for their exemplary deeds of tawakkul.

\footnotetext{
${ }^{1}$ Sürat al-Anfāl, 8:4

2 Mawdūdī, Towards Understanding al-Qur'ān, (Illinois: The Islamic Foundation, 2007), vol. 3, p. 679, cited as Mawdūdī.

${ }^{3}$ Mawdūdī, vol. 3, p. 679

${ }^{4}$ Ibn Kathīr, Abū al-Fidā' Ismā'īl, Stories of the Prophets, (Riyard: Darrussalam, 2003), pp. 318-452. Cited as Stories of the Prophets.

${ }^{5}$ Refer to Sūrat Yūsuf, 12:111.

${ }^{6}$ Sürat al-Kahf, 18:60-82.
} 
Prior to the birth of Prophet Mūsā, al-Qur'ān introduces the readers of Fir'aūn, who decree the killing of male newborn of Israelis in his empire and allowed his men to have their way with Israeli women and then burn down their house. ${ }^{1}$ Egypt at that time was a land of corruption and exploitation based purely on racial discrimination where Israeli people were enslaved and tortured. ${ }^{2}$ Moreover, plunged into arrogance and cruelty, Fir'aūn saw himself as a god on earth. He kept track of all the pregnant women in the city and secretly marked their houses so that when the mother gave birth, he would send his soldiers to kill the baby as soon as he was born. ${ }^{3}$ To protect the unborn baby Mūsā from the killing, the mother and the sister of Prophet Mūsā would take pain to ensure his safety. Her sister was always on alert on the oncoming soldiers to be prepared before they came, by rushing her mother into the bushes. ${ }^{4}$ This monitoring act on the part of his sister and hiding on the part of his mother indicates to readers the protection effort (juhd al-himāyah) put forward by the family members of Prophet Mūsā.

The strategy goes on until Prophet Mūsā was born and al-Qur'ān informs that anyone who would see him would immediately love him: "And I cast (the garment) of love (mahabbah) over you from Me." In other words, God made baby Mūsā comely and lovable and he attracted the love of the people who, on general ground would have killed him. Here again, it shows how much God loved Prophet Mūsā and how much we, readers should love him as well.

Selfless thinking leads readers to ponder the situation of Prophet Mūsā's mother, a faithful and a strong lady, who had to give birth in silence, with all the pains of delivery a woman goes through, and later she had to cover baby Mūsā's mouth to prevent his crying from being heard by Fir'aūn's people. Readers almost virtually see "the knife being taken out to cut baby Mūsā's throat". His mother was so worried, fearing that the news of his birth might reach Fir'aūn's people. She understood that if the news reached them, she would not be able to protect or hide him. How could she prevent him from crying and so betraying his presence? She knew herself,

${ }^{1}$ Sürat al-Qașās, 28:2-4; Yūsuf 'Alī in his short summary of this sūrah is of opinion that it emphasizes how Prophet Mūsā was trained by Allah for his high destiny even the period of his infantile till the end of his life was protected by Allah from the evil acts of rejection of the truth due to overweening arrogance. See 'Abd Allāh Yūsuf 'Alī, The Holy Qur'ān, (Maryland: Amana Corporation, 1983), p.801, cited as The Holy Qur'ān.

${ }^{2}$ Stories of the Prophets, p. 321.

${ }^{3}$ Tafsir Ibn Kathīr, vol. 3, p. 6.

${ }^{4}$ Ibid.

${ }^{5}$ Sūrat Tă Hāa, 20:38 
helpless and powerless except for her trust (tawakkul) in God. How stressful life could be for her and her family members; readers can never imagine! At this point God's hand intervened, making direct contact with the worried mother, and inspiring ${ }^{1}$ her with what to do:

"We revealed to the mother of Moses: 'Breastfeed him, and then when you have cause to fear for him, cast him in the river, and have no fear and do not grieve. For We shall restore him to you, and We shall make him one of Our messengers" (Sürat al-Qașās, 28:7)

Readers may question: "What sort of inspiration is this?" One could never imagine for a caring mother who was suckling her newborn baby to cast him into the river. But at the same time, she was promised of being given something else that was priceless. Indeed, this is a promise for the future, and God's promise is certain to come true. Decision must be made, finally baby Mūsā was placed in a box, put out to sail away in the river and paradoxically docked at Fir'aūn's lair. What a turn of event!

Contemplating on the event of baby Mūsā, readers observe that his mother was not a saint neither clairvoyant nor psychic but was an ordinary mother and a housewife with strong reliance in God. And yet God inspired her with two commands, two prohibitions and two glad tidings. The first command was to "suckle him" so Mūsā may recognize her milk later and to show us the lovely relationship between a mother and her child. In today's readings, suckling is a special bonding time that begins when the baby is placed skin-to-skin on the mother's chest. The heartbeat of the mother will calm the baby and will smell the breastmilk. Similarly, breastmilk's features include special factors and hormones that contribute to the optimal health, growth and development of infants. ${ }^{2}$ As for the second command, was to "cast baby Mūsā in the river" which tested the strength of a mother. Looking at the strong water currents and the big risk, his mother thought that there was always a chance where baby Mūsā would never come back to her because he might drown in the river and being eaten by the fish. With heart full of tawakkul in God, she cast him in the river, and was fully aware that God was much more merciful to baby Mūsā than to her, that He loved him more than her. God was his Lord and the Lord of the river. And the other two prohibitions were: "do not fear, nor grieve" while the two glad

\footnotetext{
${ }^{1}$ See also Sürat Tă Hāa, 20:37

2 Hanson, L., Korotkonva, M., "The Importance of Colostrum, Breastfeeding May Boost baby’s Own Immune System”, Pediatric Infectious Disease Journal; (2002, 21, pp. 816-821).
} 
tidings were: "Surely We will turn him back to you and will make him one of His Messengers." Sayyid Qutb in response to this episode said that the inspiration was not like the revelations of the Prophets; rather it was a feeling that filled her heart with strong conviction and tawakkul. ${ }^{1}$

The Qur'ānic narration goes on revealing to readers of baby Mūsā's fate where "Fir'aūn's household picked him up." Is this the security promised Mūsā's mother? Readers are in perplexing situation, asking further; does this turn of event augur the realization of the given good news? How can this happen to baby Mūsā when she feared for her son's life none other than Fir'aūn?

Pondering over the event, readers could clearly see the challenge laid down for all to understand. It is in fact, a challenge for Fir'aūn, Hāmān and the soldiers. All of them were searching to kill every newborn boy of Israeli in the country, with all the detectives around to ensure the catch and yet God effortlessly laid in their hand the helpless newborn baby, unable to defend himself even though he was in danger of being killed. Al-Qur'ān informs:

The Fir 'aün's wife said: "(Here is) a joy of the eye (qurratu 'ayn) for me and for you, slay him not, it may be that he will be of use to us or we may adopt him as a son" (Sürat al-Qașās, 28:9)

Here readers can perceive that not only God brings baby Mūsā into Fir'aūn's palace but also into his wife's heart thus offering him with tender and loving protection. Baby Mūsā needs no weapon nor authority neither money for his own safety. Meanwhile Prophet Mūsā's mother was in frantic situation. Verse ten (10) of Sürat al-Qașās describes:

"In the morning an aching void came over the heart of Mūsā's mother (așbaha fu'ād umm Mūsā färighan) and she would indeed have disclosed his identity had We not strengthened her heart so that she could continue to have faith."

The verse portrays an anguish mother with an unstable state of mind, feeling void and could not think and act. In today's medical report discloses that breastfeeding increases the level of oxytocin ${ }^{3}$ and it has beneficial effects on mothers' own mood, affect, and stress, and

\footnotetext{
${ }^{1}$ In the Shade of the Qur'àn, vol 13, p. 164.

${ }^{2}$ Sürat al-Qasās, 28:8

${ }^{3}$ Oxytocin is a hormone that acts on organs in the body including the breast and uterus. It is a chemical messenger in the brain, controlling key aspects of the reproductive system, including childbirth and lactation, and aspects of human behavior. See "You and your hormone", http://www.yourhormones.info/hormones/oxytocin/ Retrieved $7^{\text {th }}$. July 2019.
} 
breastfeeding facilitates responses to positive emotions in others. ${ }^{1}$ But in the case of Mūsā's mother, the feeling of void probably attributed to the stress of parting from her baby that lead to low level of oxytocin. Looking from another perspective, one can imagine being in the state of void at parting from her son, mother Mūsā could have betrayed herself but her faith and tawakkul in God's providence prevented her from it. This indicates the significance of tawakkul on one's life that motivate people to act as shown by mother Mūsā.

As mentioned in the following verse, mother Mūsā recovered from her difficulty (rabatnā 'alā qalbih $\bar{a}$ - strengthened her heart with faith), ${ }^{2}$ urged her daughter to follow (qușsinhi) baby Mūsā along the river. The girl intelligently moved around in disguised (bașürat bihi 'an junubin) seeking to get information. Praising the wise decision of sister Mūsā, Mawdūdī says that the sister did not go and sit back at home when she found that her brother had reached Fir'aūn's palace, but cleverly hung about the palace to watch every new development. Then, when she found that the baby was not taking to any wet-nurse, and the Fir'aūn's wife was anxious to get another one but the intelligent girl patiently waited and did not barge in. ${ }^{3}$ And al-Qur'ān informs:

"And We ordained that he refused suck at first, until his sister said: "Shall I point (adullukum) out to you the people of a house (ahl al-bayt) that will nourish and bring him up for you and be sincerely attached to him (Sürat al-Qașās, 28:12)

As stated earlier, people at the palace were in frantic on the wailing baby Mūsā. And at the precise moment the sister of Mūsā choose to come forward and proposed the ahl al-bayt. Hamka citing Ibn 'Abbās (d. $67 \mathrm{AH} / 687 \mathrm{CE}$ ), explains that people in the palace were confounded of a young girl who could suggest somebody to suckle the wailing baby Mūsā. ${ }^{4}$ They were questioning of her veracity and her relationship with the ahl al-bayt. And she wisely responded that the ahl al-bayt would like to render a little service to the monarch, so that the issue of suckling

\footnotetext{
${ }^{1}$ Kathleen M Krol, "Psychological effects of breastfeeding on children and mothers", Federal Health Gazette, (2018; 61[8]): 977-985.

${ }^{2}$ Sūrat al-Qașās, 28:10

${ }^{3}$ Mawdūdī, vol. 7, p. $575 f$.

${ }^{4}$ Hamka, Tafsir al-Azhar, (Kuala Lumpur: PTS Publication, 2019), Juzuk 20, p. 78, cited as Tafsir al-Azhar.
} 
could be resolved. ${ }^{1}$ The wife of Fir'aūn agreed to the proposal and Mūsā finally returned to her mother's bosom.

Viewing from another angle, readers can vividly see the running of God's will carrying out to show Fir'aūn, if only he could realize. It brings the Israeli baby Mūsā to them, they pick him up, they love him, they search for a suckling mother. However, God made him refuse and until his sister came in to suggest someone and they accept, not knowing that the person is Mūsā's mother. Mūsā is now is in his mother's bosom, secure, well protected by Fir'aūn, loved by his wife. God's promise always comes true and Mūsā's mother rejoices and no more grieve, ${ }^{2}$ which is the outcome her struggle, complete faith and tawakkul in God. Readers can visualize the feeling of tremor in Mūsā's mother - wajilat qulubuha - her heart full of awe as she holds her baby in her bosom for al-Qur'ān says:

"Thus, We restore him to his mother that her eye might be comforted (taqarra 'aynuha) that she might not grieve (la tahzan) and she might know that the promise of God is true." (Sūrat al-Qașās, 28:12)

Such is the outcome when readers place their trust in God. As in the case of the mother of Prophet Mūsā, who has strong conviction and trusted the guidance given to her by God, her son was safely returned to her. However, if she had taken matters into her hands by not doing what she supposed to do then Prophet Mūsā would not have survived. The question comes to mind, what benefit do we get from the Qur'ānic narration of the mother and sister of Prophet Mūsā? How relevant are their deeds in today's context?

\section{Benefit of Tawakkul}

There are numerous benefits of tawakkul that one need to understand. Among the important one is that it is the core teaching of Islam. Whether we realize it or not, it is part and parcel of Muslim life. The reason is, human is helpless without guidance. The narration of mother of Prophet Mūsā is sufficient to show how significant tawakkul in life could be. Had she not practice tawakkul we can imagine, probably baby Mūsā has no opportunity to live but died in the hands of the blood thirsty Fir'aūn. Indeed al-Qur'ān makes it clear that tawakkul is not an option. Once we have put our effort in achieving our goal the success is solely depends on God's permission. Tawakkul in this context is a requirement for God

\footnotetext{
${ }^{1}$ Ibid.

${ }^{2}$ Sürat al-Qașās, 28:13.
} 
affirmed: “... and put your trust in Allah if you are believers indeed." ${ }^{1}$ In contextualizing the story of Prophet Mūsā's mother and sister to current situation, readers have to deeply understand the concept of Qur'ānic narrations; most beautiful stories (aḥsān al-qașas) of people of the past. $^{2}$ What needs to be done is to deeply understand that:

1. Tawakkul is a requirement in life

2. Tawakkul in Allah was the manner of all the Prophets

3. Tawakkul leads to peace of mind

4. Impetus to tawakkul

\section{Tawakkul is a Requirement in Life}

There are several Qur'ānic verses that call for all to practice tawakkul in life. Some of which are:

a. "It is part of the Mercy of Allah that you do deal gently with them. Were you severe, they would have broken away from you: so pass over their faults and ask for Allah's forgiveness for them and consult them in affairs, then when you have taken a decision put your trust (tawakkal) in Allah. For Allah loves those who put their trust (al-mutawakkilin) in Him." (Sürat Āl 'Imrān, 3:159).

b. "But if they turn away, say: Allah suffices me:there is no God but He: on Him is my trust (tawakkaltu)He the lord of the Throne of Glory Supreme." (Sürat al-Tawbah, 9:129)

c. "And put your trust (tawakkal) in Him Who lives and dies not; and celebrate His praise and enough is He to be acquainted with the faults of His servants. " (Sürat al-Furqān, 25:58)

The above cited verses are some examples of which God, by His love on His servant urges us to have trust in Him. However, in verse 159 of Sürat Āl 'Imrān reminds us of the process to do before embarking into tawakkul, that is, to deal things in gentle manner, invoke God's forgiveness, consult people and then reliance. Similarly, readers find various steps applied by the mother and sister of Prophet Mūsā to save baby Mūsā, before their reliance in God. Ibn Qayyīm (d 751AH/ 1350 CE) for that matter says that "whenever the slave has good thoughts of Allah, great hope for what is with Him, true tawakkul (trust) in Him,

\footnotetext{
${ }^{1}$ Sūrat al-Mā'idah, 5:23.

${ }^{2}$ Sürat Yusuf, 12:3.
} 
then indeed Allah will never disappoint him." "Indeed, if readers practice tawakkul God will never disappoint them. Thus, it is not unusual for people of the past, particularly the Prophets, tawakkul was the manner applied by them, shown in the following.

\section{Tawakkul in Allah was the Manner of all the Prophets ${ }^{2}$}

While reading some verses of al-Qur'ān, for example that narrate on Prophet Ibrāhim, ${ }^{3}$ readers should try to focus and relate how those events of tawakkul together with that of Prophet Mūsā's mother and sister to their own personal life and challenges. In so doing readers will find that Prophet Ibrāhịm, his son Ismā'îl and his wife Hājar were greatly tested and all of them practiced the high level of tawakkul that they have been recorded in history as models of submission. Indeed, the models, featuring two Prophets - Ibrāhìm and Ismā'îl inspire readers towards the Straight Path of God. Similarly, in the deeds of Hājar, the mother of Prophet Ismā'îl, readers find an unconditional love of a mother and her endurance in practicing tawakkul by leaving baby Ismā'īl on the desert sand in search for water to quench her thirsty son. This sense of courage and tawakkul could equally be seen in the deeds of the mother and sister of Prophet Mūsā in their effort to save baby Mūsā from the blood thirsty Fir'aūn.

Another prophetic practice of tawakkul can also be observed in the Sunnah of Prophet Muhammad himself. In the event of his migration (hijrah) to Madinah from Makkah, readers can perceive how Prophet Muhammad has taken every possible means and precautions to elude and escape his enemies who sworn to kill him. ${ }^{4}$ Once he had done to his utmost ability to defend himself from any form of danger, Prophet Muhammad placed his unconditional and absolute tawakkul in his Almighty Lord. Had his Lord willed He could protect His Prophet, but the sunnah of the Prophet was to strive hard and then relied on his Lord. Al-Qur'ān commends this reliance saying:

"If ye help not (the Prophet, it is no matter): for Allah did indeed help him; when the disbelievers drove him out (during

\footnotetext{
${ }^{1}$ Ibn Qayyīm, Madārij al-Salikīn, (Al-Qāhirah: Dār al-Ḥadīth, 2003), vol 1, p. 542, cited as Madārij al-Salikin.

${ }^{2}$ Some examples: for Prophet Hūd - Sūrat Hūd, 11:156; Prophet Shu'aīb - Sūrat Hūd, 11:88; Prophet Ya'qūb -Sūrat Yūsuf, 12:67;

${ }^{3}$ Sūrat Ibrāhīm, 14:34-41; Sürat al-Anbiyā', 21:69.

${ }^{4}$ Refer to Ibn Ishạā, Muhammad, Ibn Ishaq's Sirat Rasul Allah - The Life of Muhammad, tr. Alfred Guillaume. (Oxford: Oxford University Press 1955), pp. 88-89; Stories of the Prophets, pp.199 - 206; Al Mubarakpuri, Safi al-Rahman, The Sealed Nectar: Biography of the Noble Prophet. (Riyard: Darussalam, 2011).
} 
the Hijrah): he had no more than one companion: they two were in the cave and he said to his companion [have no fear for Allah is with us]: then Allah sent down his peace (sakinah) upon him and strengthened him with forces which ye saw not, and humbled to the depths the word of the disbelievers. But the Word of Allah is exalted to the heights: for Allah is Exalted in might Wise. (Sürat Tawbah 9:40)

The outcome of unconditional tawakkul in God has resulted the feeling of calm or sakinah on Prophet Muhammad. Yùsuf 'Alī says that the Prophet never approved overweening confidence or reliance upon human strength, numbers or resources; in the hour of danger he was calm and cool courage relying on the help of God, Almighty. ${ }^{1}$ In other words, tawakkul is an attribute of one's strong faith in his Lord, deliberate in the following.

\section{Tawakkul leads to peace of mind}

Ibn Taymīyyah (d. 728AH/ 1328 CE) says:

"The heart's neglecting to seek something from Allah and place hope in Him leads inevitably to it drifting away from the worship of Him... Obedience is the key to tawakkul. The praiseworthy are those who have actualized [Allah's words], "It is You (alone) we worship, and You (alone) we ask for help" and "So worship Him and rely upon Him." They sought assistance from Him by obeying Him, confirming that $\mathrm{He}$ is their Lord and that He must be worshipped alone through obedience to Him and to His Messenger."

What Ibn Taymiyyah intends to highlight from the above citation is tawakkul means an unconditional reliance and absolute submission to God. Tawakkul also refers to obey and fulfill all the rules and regulations set by God. While submitting to God, the element of sincerity comes into play. This could be in the form of:

a. loyal submission to all of God's ruling;

b. obey intelligently (contextualize) of God's ruling;

c. conscious state of mind in fulfilling the duties

d. sincere state of heart in internalizing the duties

e. approve manner of submission and obedience exemplified in the deeds of Prophet Muhammad

\footnotetext{
${ }^{1}$ The Holy Qur'ān, p. 358.

${ }^{2}$ Ibn Taymìyyah, Majmū 'al-Fatāwā, (Bayrūt: Dār Ibn Ḥazm, 2011), vol 10, p. 32.
} 
In other words, when a person has a strong faith in God, he will put his unconditional trust in Him. He will submit by obeying and fulfilling all God's ordinances. This act of submission becomes continuous part of his daily activity. Due to this continuity act of submission, it leads him to pious life known also as God's consciousness (taqwā). Taqwā in turn, is the force that can restrain man from evil and wickedness. It is this consciousness of God that brings the tranquility on the heart and the mind of people. ${ }^{1}$ God says:

"And whoever fears Allah, He will make for him a way out And will provide for him from where he does not expect. And whoever relies upon Allah - then He is sufficient for him.

Indeed, Allah will accomplish His purpose. Allah has already set for everything a [decreed] extent (Sürat al-Țalāq, 66:2-3)

Just like the deeds of the mother of Prophet Mūsā, who completely trusted God and obeyed the command intelligently by placing baby Mūsā in a box and later cast him into the river; demonstrate to readers of the outcome of tawakkul. Despite being in an unstable state of mind, which is human myriad, she held onto her grit and managed to move forward by remembering God's promise "do not fear, nor grieve." And by God's Mercy, the sister of Prophet Mūsā upon her mother's request, was inspired to seek whereabout her brother, to get information on his state and to assist the people of palace to get a wet-nurse for suckling, who later turned out to be her own mother. All of these events illustrate to readers the aspects of loyalty, obedience, conscious state of mind, sincere heart and precise act of doing things that contribute to peace of mind and happiness to all; the mother, the sister and baby Mūsā. The question that arises is, what could there be the impetus to tawakkul?

\section{Impetus to Tawakkul}

In today's world, with its prevailing idea of immediate gratification, to develop tawakkul seems to be a little bit difficult. Although it is known to readers that all matters in human's life have been decreed by God, yet man continues to go after things at all costs despite those things might not belong to him. The barrier towards tawakkul is due to disease of the heart ${ }^{2}$ for not having faith or conviction in the promises and benefits of God's rulings,

\footnotetext{
1 "Those who believe (in the Oneness of Allah), and whose hearts find rest in the remembrance of Allah, Verily, in the remembrance of Allah do hearts find rest. (Sürat al-Ra'd, 13:28)

${ }^{2}$ Sürat al-Jäthiyah, 45:23
} 
stipulated in al-Qur'ān and exemplified by ahādìth of the Prophet. So, the impetus to tawakkul is to mindset one's thinking to plan, train, apply and strive for reliance in God. When God says that He holds man's life then mankind really needs to believe that He does. Imagine that the mother of Prophet Mūsā who upon God's inspiration does not cast baby Mūsā in the river and doubted His promise; today one might hear the demise of baby Mūsā was due to his mother's insubordination to God. Likewise, the sister of Prophet Mūsā who upon the request of her mother, refused to search for baby Mūsā's whereabout, now one might accuse her as an insolent daughter. Hence, in practical, to develop the incentive to tawakkul, one needs to do the following deeds:
a. Start with al-Qur'ān
b. Repent to God regularly
c. Seek His help and be patient ${ }^{1}$

\section{a. Start with al-Qur'ān}

As it is duly known to all al-Qur'ān is one of the authentic references of Islam and anyone who intends to develop tawakkul must refer to this reliable source. Then once the teachings are comprehended well one must infuse the Qur'ānic teachings in life such that one becomes a living, walking, talking embodiment of the teachings.

In other words, al-Qur'ān helps man to develop tawakkul by presenting Himself and His Asma' al-Husna $\bar{a}^{2}$ (Beautiful names), Authority and Attributes. With His Attributes, God provides to all of His creations their sustenance, kindness, good or evil, blessing, richness, poverty, healthy, death etc. Readers will put their trust in God for He is: "The Creator of all things, and He is the Wakil (Trustee, Disposer of affairs, the Guardian) over all things." "A And whoever relies on Him, He is the best to rely upon: "All-Sufficient is Allah as a disposer of affairs.", Equally, readers of al-Qur'ān will find with certainty that God is the Allstrong, the All-Knower, Whose Knowledge grasps in the most perfect manner all things, hidden or open, all things are known to Him. He is Ever living and all that is on earth and heaven belongs to Him and $\mathrm{He}$

\footnotetext{
1 Cited from Deana Nassar, "Trust in Allah does not just happen" https://aboutislam.net/shariah/refine-your-heart/advice/trust-allah-doesnt-just-happendevelop/, retrieved: 7 July 2019.

${ }^{2}$ Refer to Sürat al-Hashr, 59:24 - "The most beautiful names belong to Him (Allah)."

${ }^{3}$ Sürat al-Zumar, 39:62.

${ }^{4}$ Sürat al-Nisā', 4:171.
} 
stands in needs of nobody. Hence, the more readers know of God's Attributes the stronger reliance be on Him.

\section{b. Repent to God Regularly}

To err is human myriad. At times, whether knowingly or unknowingly man makes mistakes and feeling guilty of those sins become the first step towards tawbah or repentance. God says:

"O you who believe! Turn to Allah with sincere repentance (tawbatan nasūhā)! It may be that your Lord will expiate from you your sins...( Sürat al-Taḥìm, 66:88).

In the verse, it specifically points out that sincere tawbah is not merely an utterance of words rather it subjects to the strong intention of the doer to forsake the sinful acts forever, strong determination to restore other's right or property involving wrongdoings on others and solid commitment not to repeat of the past mistake before death looms over him. God says:

"And whoever does evil or wrongs himself but afterwards seeks Allah's forgiveness, he will find Allah Oft Forgiving, Most Merciful" (Sürat al-Nisā' 4:110).

Once a person feels ashamed of his past evil deeds and determines to change, all he needs to do is to put his tawakkul in the power of tawbah by sincerely fulfilling all rules and ordinances set by God. Indeed, sincere tawbah has several virtues, ${ }^{1}$ such as:

i. Tawbah paves way for success (Sūrat al-Nür, 24:31)

ii. Tawbah keeps us away from hardships and trials (Sürat Tawbah, 9:126)

iii. Tawbah helps clear our conscience (Sürat al-Tahrìm, 66:88)

iv. Tawbah pleases God (Sürat al-Baqarah, 2:222)

v. Tawbah is a life transformational process (Sürat al-Baqarah, 2:160)

vi. Tawbah makes the supplication ( $d u$ ' $\bar{a}$ ') more 'worthy' of a response

(Sūrat al-Zumar, 39:53)

Knowing the merits of tawbah and tawakkul in its power, in practicum; a person should choose a time where he could be in khulwah or solitary, be in a state of peace and be truly near to God by performing his saläh and dhikr (God's remembrance). In the beginning one may feel dry on his tongue but regular and persistent deeds will make tawbah

Cited from P Jaafar Ali Khan, "Merits and rewards of tawbah" https://www.iqrasense.com/repentance-tawbah/merits-and-rewards-of-tawbahrepentance-to-allah.html, retrieved 7th July 2019. 
a session to look forward for it rejoices and awakens the heart. A heart which is alive develops a stronger sense of tawakkul in God and whatever events confront the beholder, he is able to face them amicably, discussed in the following discussion.

\section{c. Seek His Help and be patient}

God says:

"Be sure We shall test you with something of fear and hunger, some loss in goods, lives, and the fruits of your toil. But give glad tidings to those who patiently persevere. Those who say, when afflicted with calamity, 'To Allah we belong, and to Him is our return.' They are those on whom descend blessings from their Lord, and mercy. They are the ones who receive guidance." (Sürat al-Baqarah, 2:155-157)

Life as pointed by the above citation is full of test. During times of deep trial, despair, and sadness, al-Qur'ān requests readers to inculcate "patient, perseverance and prayer." Indeed, God reminds that people of the past have suffered and had their faith tested. Just like the mother and sister of Prophet Mūsā were severely tested but due to their patience and tawakkul in life they succeeded. On another plane, Ibn Qayyim in his Miftāh Dār al-Sa 'ādah invites readers to critically ponder:

"How many great blessings and favors Allah bestows by means of trials and tests?... how Prophet Ādam's trial and test ended with Allah choosing him, bringing him close to Him, accepting his repentance, guiding him and raising him in status?"

Think about how Prophet Ibrāhīm's trial and patience ended, and how he was ready to offer himself for the sake of Allah. Think about where his willingness to offer himself for the sake of Allah took him; because he strove to support the religion of Allah, Allah took him as His close friend... Allah increased his progeny, blessed them and made them numerous to the extent that they filled the world, and He granted Prophethood and Scriptures to his progeny only, from among whom he brought forth Prophet Muhammad, and commanded him to follow the path of his father Prophet Ibrāhīm...

All those tests and trials were, in reality, a blessing by means of which Allah increased him in honor and virtue and caused Prophet Muhammad to attain the highest status. This is the situation of his heirs [the scholars and righteous] after him, the best and then the 
next best; each of them has a share of trials, by means of which Allah causes him to attain perfection commensurate with the extent to which he follows their Prophet."

Readers can deduce that test and tribulation are part and parcel of life. The forthright purpose of those tests are to raise the status of believers that commensurate their patience and tawakkul to God. The question is how readers could be motivated to get closer to God and to seek His help? At times, in negative tone; why continuous $d u$ ' 'a' receive no response from Him? To answer these questions Ibn Qayyīm requests readers to consider the following four conditions: ${ }^{2}$

i. Have certainty that Allah will answer your $d u$ ' $\bar{a}$ '.

The Prophet said, "Ask Allah with certainty that He will answer your prayers.",3

ii. Show submissiveness and devotion during your $d u$ ' $\bar{a}$ '.

The Prophet said, "Know that Allah will not accept the supplication from an absent heart."

iii. Be patient and do not hasten for an answer.

The Prophet said: 'The $d u$ ' $\bar{a}$ ' of any worshipper will continue to be responded to, as long as... he is not hasty"

iv. Continue to gain a lawful means of living.

The Prophet narrated a story about a man asking Allah, saying "O Lord! O Lord!" but his food was unlawful, his drink was unlawful, his clothing was unlawful, and he was nourished unlawfully; so how can he be answered?!"

The four conditions brought forth by Ibn Qayyīm suffice for readers to answer why the existence of emptiness in their hearts while praying or supplicating. This emptiness is resulted from their selfish intention for the submission done was not for seeking the pleasure of the Almighty

1 Ibn Qayyīm, Miftāh dār al-Sa'ādah, (Dimashq: Dār 'Ilm al-Jawzī, 2011) vol. 1, pp.229-331, cited as Miftāh dār al-Sa 'ādah.

${ }^{2}$ Ibid, vol. 1, 404.

${ }^{3}$ Jāmi ‘ al-Tirmidhī, vol. 6, Book 47, Hadīth 3372, cited as Jāmi ‘ al-Tirmidhī.

${ }^{4}$ Ibid, vol. 6, Book 47, Hadīth 3479.

5 Ibn Majah, Muḥammad ibn Yazīd, Sunan Ibn Majah, (Bayrūt: Dār al-Kutub al'Ilmìyyah, 2008), vol. 5, Book 34, Hadith 3853

${ }^{6}$ Jämi' al-Tirmidhī, vol. 5, Book 44, Hadìth 2989. 
God. Similarly, demanding an immediate gratification due to impatience heart leads to emptiness, despondent and frustration. This means that to develop tawakkul requires patience and pure intention to seek the pleasure of Almighty God. It is a journey of enormous spiritual growth. Hence the four conditions as outlined by Ibn Qayyim must be fulfilled so that readers' supplication be answered just like the deeds of patience and submission practiced by the mother and sister of Prophet Mūsā that contributed to success in their life.

\section{Conclusion}

In short, tawakkul means reliance and trust in Allah upon effort in one's affair. It is a two-way relationship whereby a person takes a responsibility on his affair and employing God's resources and spiritual insights and then relies on Him. The person will always reach the intended result and will not fear anything, because such a person sees God as the One who can affect things in this world. However, if one does not rely on God, he will be constantly worried, for he has forgotten his true Guardian and has put his faith in unreliable entities. The Qur'ānic narration on the mother and sister of Prophet Mūsā prove to be an important lesson for all of us today; to be emulated in particular to develop tawakkul in life during peace period and time of conflict. Patience and obedience to God become the key ingredients for successful life in this world and the world to come.

\section{References}

Ibn Manzūr, Lisān al- 'Arab, Bayrūt: Dār al-Ṣadr, 1994.

Ibn Abī al-Dunyā: Certainty and Morality", Leonard Librande, Studia Islamica, No. 100/101, 2005.

Al-Muhāsibi, al-Hārith ibn Asad, Al-Makāsib wa al-Rizq al-Halāl wa Haqiqqatal-

Tawakkul, Al-Qāhirah: Maktabah al-Qur'an, 1984.

Ibn Kathīr, Abū al-Fidā' Ismā' '̄l, Stories of the Prophets, Riyard: Darrussalam, 2003. Ibn Kathīr, Abū al-Fidā' Ismā '̄il, Mukhtașar Tafsīr Ibn Kathīr, Bayrūt: Dār al-Qalam, 1991. Sayyid Qutb, In the Shade of the Qur'ān, Leicester: The Islamic Foundation 1999. Ibn Qayyīm, Miftāh dār al-Sa'ādah, Dimashq: Dār 'Ilm al-Jawzī, 2011. Ibn Qayyīm, Madārij al-Salikīn, Al-Qāhirah: Dār al-Ḥadīth, 2003.

Al-Tirmidhī, Muḥammad ibn 'Isā, Jāmi ' al-Tirmidhī, (London: Darussalam, 1970. Ibn Majah, Muhammad ibn Yazīd, Sunan Ibn Majah, (Bayrūt: Dār al-Kutub al-

'Ilmiyyah, 2008. 


\section{AL-ITQĀN}

JOURNAL OF ISLAMIC SCIENCES AND COMPARATIVE STUDIES

\section{Volume: 3}

\section{Issue No. 2}

December 2019

EDITOR IN-CHIEF

Dr. Wan Mohd Azam Mohd Amin

\section{MANAGING EDITOR}

Dr. Masitoh Ahmad

\section{EDITORIAL BOARD}

Dr. Muhammad Afifi al-Akiti, Oxford

Dr. Muhammad Kamal Hassan, IIUM

Dr. Syed Arabi Aidid, IIUM.

Dr. Hassan Basri Mat Dahan, Universiti Sains Islam Malaysia,

Nilai, Negeri Sembilan.

Dr. Kamaruzaman Yusuff, Universiti Malaysia Sarawak,

Kota Semarahan, Kucing.

Dr. Kamar Oniah, IIUM.

Dr. Mumtaz Ali, IIUM.

Dr. Siti Akmar, Universiti Institut Teknologi MARA, Shah Alam

Dr. Thameem Ushama, IIUM. 